\title{
HOW MUCH IS THE WORKING-AGE POPULATION SAVING?
}

\author{
Alicia H. Munnell, Francesca Golub-Sass and Andrew Varani* \\ CRR WP 2005-12 \\ Released: October 2005 \\ Draft Submitted: October 2005
Center for Retirement Research at Boston College
550 Fulton Hall
140 Commonwealth Ave.
Chestnut Hill, MA 02467
Tel: 617-552-1762 Fax: 617-552-0191
http://www.bc.edu/crr

\begin{abstract}
* Alicia H. Munnell is the Director of the Center for Retirement Research (CRR) and the Peter F. Drucker Professor of Management Sciences at Boston College's Carroll School of Management. Francesca GolubSass is a research associate at the Center. Andrew Varani is an undergraduate research assistant at the CRR. The research reported herein was performed pursuant to a grant from the U.S. Social Security Administration (SSA) to the Center for Retirement Research at Boston College (CRR). The findings and conclusions are solely those of the authors and do not represent the views of SSA, any agency of the Federal Government, or Boston College.
\end{abstract}

(C) 2005, by Alicia H. Munnell, Francesca Golub-Sass, and Andrew Varani. All rights reserved. Short sections of text, not to exceed two paragraphs, may be quoted without explicit permission provided that full credit, including (C) notice, is given to the source. 


\title{
About the Center for Retirement Research
}

The Center for Retirement Research at Boston College, part of a consortium that includes a parallel centers at the University of Michigan and the National Bureau of Economic Research, was established in 1998 through a grant from the Social Security Administration. The goals of the Center are to promote research on retirement issues, to transmit new findings to the policy community and the public, to help train new scholars, and to broaden access to valuable data sources. Through these initiatives, the Center hopes to forge a strong link between the academic and policy communities around an issue of critical importance to the nation's future.

\author{
Center for Retirement Research at Boston College \\ 550 Fulton Hall \\ 140 Commonwealth Ave. \\ Chestnut Hill, MA 02467 \\ phone: 617-552-1762 fax: 617-552-1750 \\ e-mail: crr@bc.edu \\ http://www.bc.edu/crr
}

\section{Affiliated Institutions:}

American Enterprise Institute

The Brookings Institution

Center for Strategic and International Studies

Massachusetts Institute of Technology

Syracuse University

Urban Institute 


\begin{abstract}
:
This paper addresses how much individuals are saving for retirement. The standard measure, the personal saving rate reported in the official U.S. National Income and Product Accounts (NIPA), has fallen dramatically and in 2004 stood at a dismal 1.8 percent of disposable personal income. But is this indicator an accurate measure of saving behavior? NIPA combines the saving of the working-age population with the dissaving of retirees. This study attempts to separate the saving of these two groups.

Three conclusions emerge from the analysis. First, adjusting the NIPA personal saving rate shows that personal saving by the working-age population is significantly higher than the reported national rate. Moreover, allocating a portion of business saving to working-age households further raises their saving rate. Second, commentators should be careful not to double count saving through employer-sponsored plans by referring to pension saving and personal saving as if they were different components. In fact, for most of the time between 1980 and 2003, pension saving accounted for all of personal saving. Finally, the analysis (inadvertently) helps explain the puzzle surrounding the collapse of the total NIPA personal saving rate beginning in the early 1980s. While capital gains were part of the story in the1990s, most of the downward trend can be explained by changes in the saving rate of those 65 and over.
\end{abstract}


How Much Is the Working-Age Population Saving?

It is crucial that today's workers save for retirement. This is because Social Security replacement rates will decline due to increases in the Normal Retirement Age, rising premiums for Medicare, higher personal income taxes, and potential adjustments to restore financial balance to the system. And accumulations in 401(k) plans may well be much lower than people anticipate. As such, personal saving will become increasingly necessary for retirement security.

So how much are individuals saving for retirement? The standard measure, the personal saving rate reported in the official U.S. National Income and Product Accounts (NIPA), has fallen dramatically and in 2004 stood at a dismal 1.8 percent of disposable personal income. But is this statistic an accurate measure of saving behavior?

The NIPA personal saving rate is a much beleaguered statistic. Economists complain that consumer durables (such as automobiles and dishwashers) that generate services over an extended period of time, are treated as consumption rather than investment and interest income and outlays are not adjusted for inflation. Analysts interested in retirement security bemoan the exclusion of capital gains, because these gains may help finance post-retirement consumption. This study focuses on a new issue - namely, NIPA combines the saving of the working-age population with the dissaving of retirees. This aggregation would not distort trends in saving if retirees were a constant proportion of the population, but with the retirement of the baby boom generation, their ranks will swell. As a result, even if the saving of each age group remains unchanged, the aggregate saving rate will decline.

This study thus attempts to separate the saving out of current income done by the working-age population (those under age 65) from that undertaken by retirees (those 65 and over). The first section describes the NIPA accounts. The second section estimates the share of NIPA personal saving that belongs to those under age 65 . The third section broadens the calculation of household saving to include business saving. 


\section{THE PURPOSE AND DERIVATION OF NIPA SAVING}

The National Income and Product Accounts (NIPA) are designed to measure current production and income derived from that production. Saving in the NIPA measures the extent to which society sets aside currently produced resources for the purpose of increasing its future standard of living. The amount set aside includes: current income not consumed by households; current earnings retained by businesses; and current revenues not spent by government.

This study begins with current income not consumed by households, or "personal saving," - the measure most frequently discussed in the media. In the NIPA, the household sector is defined very broadly. It includes nonprofit institutions that primarily serve households, such as those providing medical care, recreation, education, research, religious and welfare activities. It also includes pension funds, some insurance reserves, private trust funds, and unincorporated businesses.

In the NIPA framework, personal saving is the difference between personal disposable income and personal outlays. Personal disposable income is personal income less tax payments from the household sector to government. As shown in Table 1, personal income consists of wages and salaries; supplements to wages and salaries (pensions, health insurance, etc.); proprietors', rental, and asset income (interest and dividends); and transfer payments less contributions for social insurance (Social Security and Medicare). Personal outlays are mainly consumption expenditures on durables, nondurables, and services. In 2004, the personal saving rate equaled personal saving ( $\$ 151.8$ billion) divided by disposable personal income ( $\$ 8,664.2$ billion) or 1.8 percent.

Table 1. Derivation of NIPA Personal Saving, 2004 Billions of dollars

\begin{tabular}{|c|r|}
\hline Personal Income & $9,713.3$ \\
\hline Compensation of employees & $6,687.6$ \\
\hline Wages and salaries & $5,389.4$ \\
\hline Supplements (pensions, health insurance etc) & $1,298.1$ \\
\hline Proprietors, rental, interest, and dividend income & $2,420.3$ \\
\hline Personal current transfer receipts & $1,427.5$ \\
\hline Government benefits & $1,394.5$ \\
\hline Transfers from business & 33.0 \\
\hline Less: Contributions for Social Insurance & 822.2 \\
\hline Less: Personal current taxes & $1,049.1$ \\
\hline
\end{tabular}




\begin{tabular}{|l|r|}
\hline Equals: Disposable personal income & $8,664.2$ \\
\hline Less: Personal outlays & $8,512.5$ \\
\hline Equals: Personal saving & 151.8 \\
\hline
\end{tabular}

Source: Bureau of Economic Analysis. 2005. National Income and Product Accounts. Table 2.1.

For most of the postwar period, the NIPA personal saving rate displayed a modest upward trend with very little variation (Figure 1). Since the early 1980s, however, the rate has dropped precipitously from around 11 percent of personal disposable income in 1980 to 1.8 percent in 2004 .

Figure 1. Personal Saving as a Percentage of Disposable Personal Income, 1950-2004

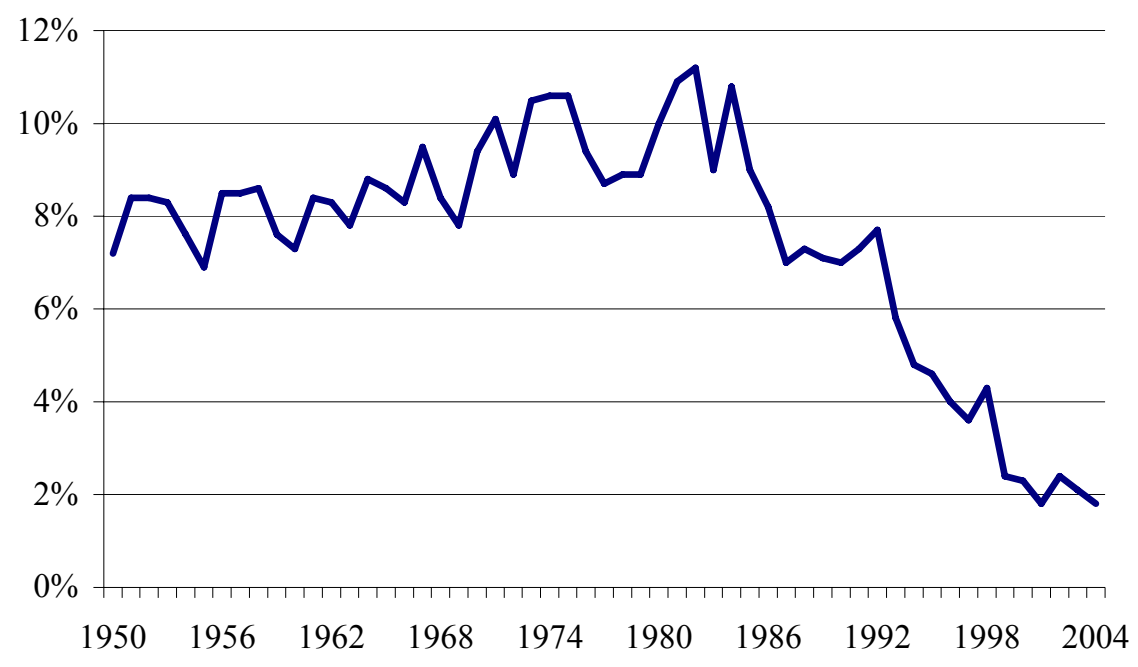

Source: Bureau of Economic Analysis. 2005. National Income and Product Accounts. Table 2.1.

Economists have spent a lot of energy attempting to explain the precipitous drop, but with little success. For example, some researchers point to the rise in the wealth-toincome ratio due to capital gains in the stock and housing markets (Gale and Sabelhaus 1999). Appreciation in the value of existing assets would reduce the need for households to save out of current income. Unfortunately, the rise in the wealth ratio is concentrated in the years after 1994, and therefore does not explain why the saving rate took a nose dive beginning in the early 1980s. Other economists have emphasized mortgage refinancing as a way to withdraw housing equity to finance current consumption (Catte et al 2004). Again, this is an important phenomenon in the late 1990s, but does little to explain the decline in saving in the earlier years. Thus, the decline remains a puzzle. 
Although this study was not designed to solve the puzzle, looking at saving by age group does help explain the decline

\section{THE SAVING OF THE WORKING-AGE POPULATION}

A confounding aspect of the personal saving rate is that it combines the saving of the working-age population with the dissaving of those 65 and over. With regard to the question of retirement preparedness, the saving by the working-age population is the key concern. Although the extent to which older people dissave is a source of controversy in the economics literature, ${ }^{1}$ the very structure of the accounts virtually ensures that the NIPA saving rate for the elderly will be negative. Specifically, the NIPA includes all contributions and interest and dividend income in employer pension plans, including 401(k) plans, in personal income. Benefits paid from these plans, on the other hand, are not included in the income of retirees but are treated as a drawdown of accumulated savings. That is, much of the money that funds the current consumption of the elderly is not counted as current income. (NIPA treats Social Security just the reverse.

Contributions are not included in the income of workers, while benefits are counted as the income of retirees.)

If retirees were a constant portion of the population, the negative saving by the elderly would not help explain the fall in the aggregate saving rate. But the retiree portion of the population has been increasing gradually and will rise sharply with the aging of the baby boomers (Figure 2). Their increasing proportion means that the dissaving of the elderly will dramatically reduce the NIPA saving rate over time.

Figure 2. Percent of Population 65 and Over, 1950-2050

\footnotetext{
${ }^{1}$ In examining the extent to which households dissave in retirement, economists have focused primarily on nonannuitized wealth - that is, they tend to ignore pensions and Social Security benefits. A series of studies looking at panel data for the 1960s, 1970s, and early 1980s finds that the elderly draw down their nonannuitized financial assets at a relatively slow rate of between 1 and 5 percent per year. The results for the late 1980s and 1990s differ from the earlier studies in that they show either no change or increases in non-annuitized assets. For a summary of the literature see Haider et al. 2000.
} 


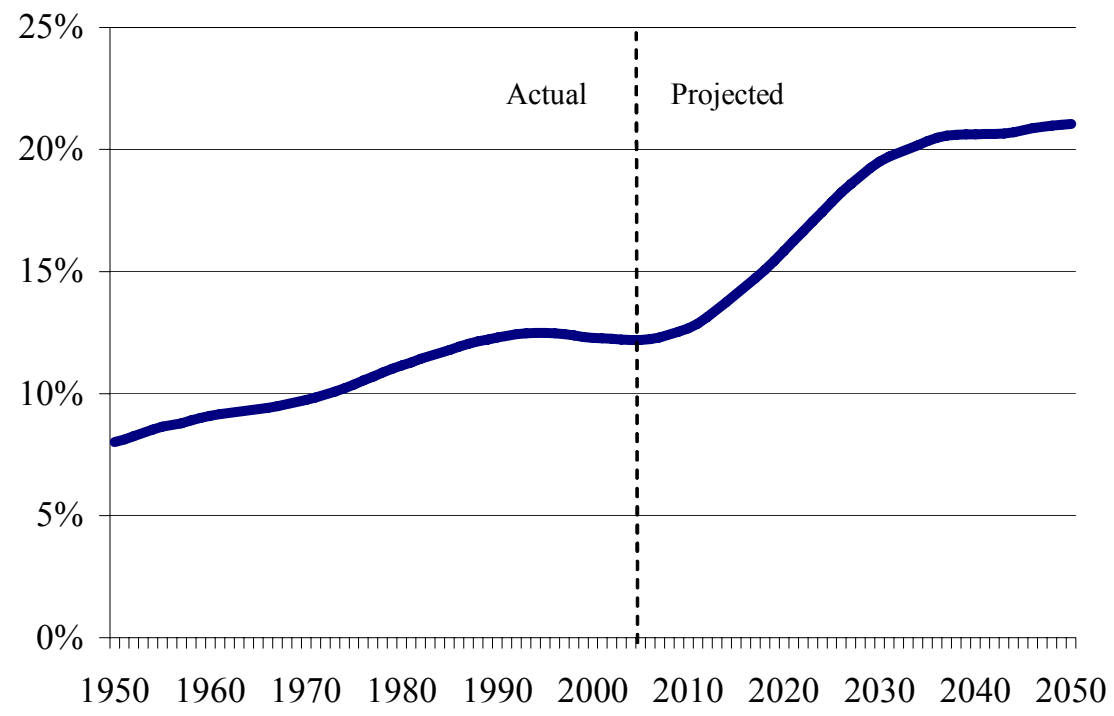

Source: Social Security Administration. 2005. Annual Report of the Board of Trustees of the Federal Old-Age and Survivors Insurance and Disability Insurance Trust Funds. Table V.A2.

By removing retirees' income, taxes and outlays from the calculation of the saving rate, this study adjusts the benchmark personal saving rate reported in the NIPA to provide a more accurate picture of saving for retirement by the working-age population. ${ }^{2}$ This exercise is somewhat tenuous. Saving is the small difference between two very large numbers - disposable personal income and personal outlays. Slight modifications in assumptions can have a significant impact on the measured saving rates of the two populations. Thus, the goal of this exercise is not to justify each assumption used to divide income, taxes, and outlays between the working-age and 65 and over components of the population. Rather, it is simply to make the point that workers and retirees have different patterns. And as the population ages, the NIPA saving rate will become an increasingly poor measure of the extent to which the working-age population sets aside resources out of current income to support itself in retirement.

Calculating the saving rate for the working-age population involves the use of government household surveys of income, wealth, and expenditures to divide each component of NIPA income and outlays between the under 65 and 65 and over

\footnotetext{
${ }^{2}$ A note of caution is important here. The NIPA saving rate is not necessarily a measure of retirement adequacy - a high saving rate does not guarantee a comfortable retirement. Investment choice and investment performance are also important.
} 
population. The gruesome details of the calculations for 2001 are described in the Appendices; the following simply provides the flavor of the process. ${ }^{3}$ For example, the major component of NIPA personal income is compensation of employees. Here the allocation is straightforward. Total compensation of employees is divided between the two age groups based compensation of employees by age reported in the Department of Labor's Consumer Expenditure Survey. The second largest component - proprietors, rental, interest, and dividend income - is difficult and messy to allocate, requiring wealth holdings by age from the Federal Reserve's Survey of Consumer Finances and asset data from the Flow of Funds. The third largest component of personal income - government benefits - consists mainly of Social Security, Medicare and Medicaid. Again the allocation is straightforward, based on data by age from the relevant agencies.

Personal taxes are divided between the elderly and non-elderly population using tax payments by age from the Consumer Expenditure Survey.

On the outlays side, most of the expenditures are divided between those 65 and over and the working-age population based on data by age in the Consumer Expenditure Survey. The major challenge on the expenditure side is medical care, because the NIPA includes costs paid by health insurance companies and the household surveys report only out-of-pocket expenses. Thus, data on national health expenditures is used as the basis for determining the amount of NIPA medical care expenditures belonging to those below 65 and those 65 and over.

Table 2 displays the NIPA personal saving rate for the working-age population, those 65 and over, and the total population in 2001. According to our estimates, in 2001 the reported NIPA rate of 1.8 percent for the nation consists of a positive saving rate of 4.4 percent for the working-age population and a negative rate of -11.9 percent for those 65 and over.

Table 2. Personal Saving for the Working-Age Population, 65 and over, and Total, 2001 Billions

\begin{tabular}{|l|c|c|c|}
\hline Item & $\begin{array}{c}\text { Working- } \\
\text { Age }\end{array}$ & 65 and over & Total \\
\hline
\end{tabular}

\footnotetext{
${ }^{3}$ The year 2001 was selected as the starting point for the project because it is the date of the most recent Survey of Consumer Finances, which contains crucial wealth data.
} 


\begin{tabular}{|l|r|r|r|}
\hline Disposable personal income & $\$ 6,278$ & $\$ 1,209$ & $\$ 7,487$ \\
\hline Personal outlays & 6,001 & 1,353 & 7,355 \\
\hline Saving & 277 & -144 & 133 \\
\hline & & & \\
\hline Addendum: & & & \\
\hline Personal saving rate & $4.4 \%$ & $-11.9 \%$ & $1.8 \%$ \\
\hline
\end{tabular}

Source: Bureau of Economic Analysis. 2004. National Income and Product Accounts. Table 2.1 and authors' calculations. See Appendix 1 for calculation details.

Figure 3 applies the same methodology for separating the income, taxes and outlays for the two age groups for the period 1980 through 2003. Once the elderly are separated out of the NIPA accounts, the decline in saving is much less dramatic. The divergence between the saving rate for the working-age population and the total rate increases over time. Today, the saving rate for the working-age population appears to be heading towards six percent as the total rate hovers around two percent.

Figure 3. NIPA Personal Saving Rate: Total and Working-Age, 1980-2003

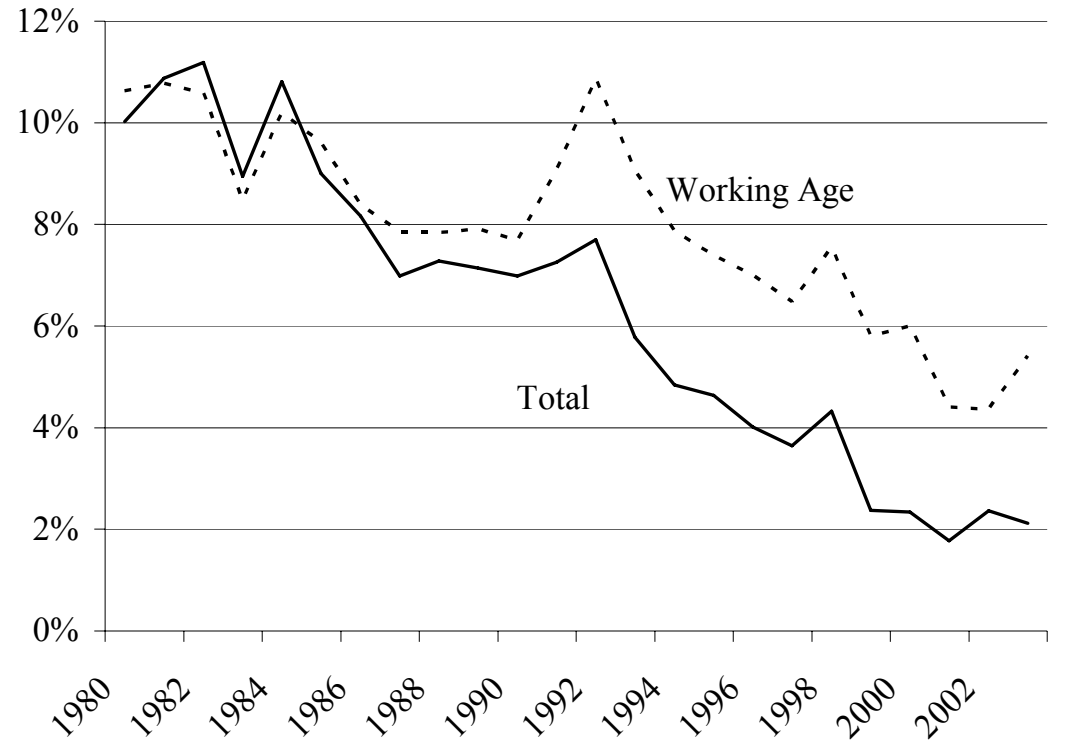

Source: Bureau of Economic Analysis. 2005. National Income and Product Accounts. Table 2.1 and Authors' calculations. See Appendix 1 for details.

One obvious question is why the saving rate for the working-age population and the total personal saving rate appear to increasingly diverge. The answer appears to hinge on the dramatic decline in the saving rate of those 65 and over (Figure 4). Here 
three factors play an important role. First, on the income side, pension income as a percent of total income of households 65 and over has increased from 14 percent of the total in 1980 to 19 percent in 2002 (Chen 1992 and U.S. Social Security Administration 2002). As noted above, pension benefits are not counted as part of NIPA income.

Assuming that all pension benefits are consumed, the increase in importance of this noncounted source would reduce the saving rate of those 65 and over by 5 percentage points.

Figure 4. NIPA Personal Saving Rate: Total and 65and over, 1980-2003

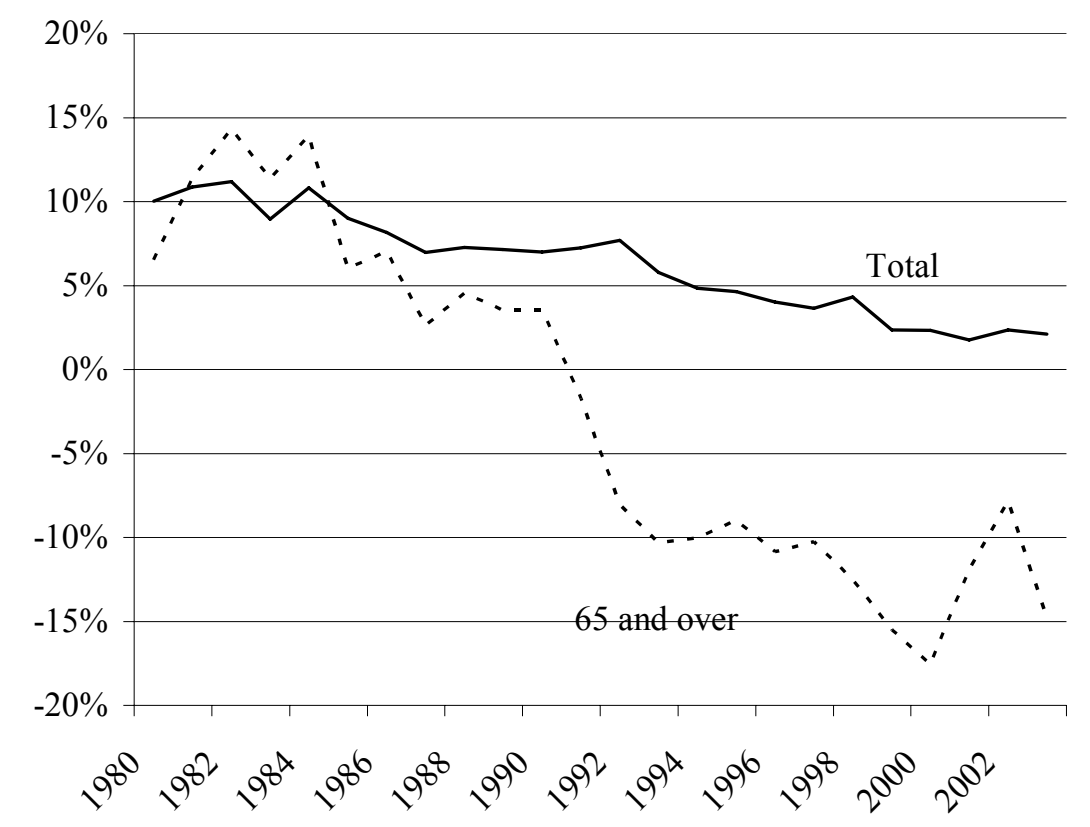

Source: Bureau of Economic Analysis. 2005. National Income and Product Accounts and authors' calculations. See Appendix 1 for details.

The second factor, also on the income side, is the decline in nominal interest income as inflationary pressures waned in the 1980s. The NIPA saving rate is calculated using nominal values of income and outlays. If inflation simply scaled up the value of these components it would have little effect on the saving rate. Inflation, however, tends to raise interest income more than the change in the general price level. ${ }^{4}$ As a result the saving rate varies with the rate of inflation. Because the household sector tends to be a

\footnotetext{
${ }^{4}$ The required adjustment to the nominal interest rate to leave consumers as well off in an inflationary economy as in a non-inflationary economy is equal to $\pi+\pi \mathrm{i}$, where $\pi$ is the rate of inflation and $\mathrm{i}$ is the interest generated by the asset. The first term compensates for the loss of purchasing power on the value of the asset and the second term compensates for the loss of purchasing power on the interest generated by the asset (Perozek and Reinsdorf 2002).
} 
net lender to other sectors, net interest income, and therefore saving rates, tend to be high when inflation is high and to decline as inflation drops. The decline in inflation has a disproportionately large effect on the saving rate of those 65 and over, because they receive a large percentage of interest income.

The third important factor contributing to the decline in the saving rate for those 65 and over occurs on the outlay side. Health care expenditures for households as a whole increased from 11.6 percent of total outlays in 1980 to 19.5 percent in 2003 . Since the elderly account for a disproportionate share of these outlays, the increase disproportionately raised their outlays and lowered their saving rate.

In short, a number of factors have combined to bring down the saving rate of those 65 and over. The result has been that the total NIPA personal saving rate increasingly understates the saving of the working-age population. As noted above, the discrepancy will only increase as the share of the population 65 and over rises. Therefore, to understand the extent to which current workers are saving for retirement it will become increasingly important to separate the saving of those 65 and over from that of the working-age population.

\section{BEWARE OF DOUBLE COUNTING!!}

Sometimes when researchers and commentators assess saving for retirement, they cite Social Security, employer-sponsored pensions, and personal saving as if these are three independent sources of retirement income. The problem with this assessment is that much of personal saving in the NIPA is pension contributions and earnings on accumulated pension assets. Thus, commentators may well be double counting.

To estimate NIPA personal saving excluding saving in employer-sponsored plans requires the subtraction of three amounts: 1) employer contributions to both defined benefit and defined contribution plans; 2) employee contributions, primarily to 401(k) plans; and 3) the earnings on the accumulated plan assets. Employer contributions and earnings on pension assets come right out of the NIPA accounts - pro-rated to reflect the proportion attributable to the working-age. An estimate of employee 401(k) contributions is derived by subtracting NIPA employer contributions from total contributions as reported in the Department of Labor's Form 5500. Once the saving figure is reduced to exclude pension saving, it is divided by personal disposable income to derive the non-pension saving rate for the working-age population.

As shown in Figure 5, pension saving for most of the period since 1980 accounts for virtually all the saving of the working-age population. Since the mid 1990s, saving 
outside of pensions for the working-age population has actually been negative. This pattern most likely reflects the "wealth effect" created by the enormous run-up in the stock market in the second half of the 1990s and more recently the tapping of housing equity in the wake of the housing boom. In each case, households see an increase in their wealth that does not arise from current income and therefore is not reflected in NIPA income. However, the increase in wealth causes households to spend more and thereby reduce the NIPA saving rate.

Figure 5. NIPA Personal Saving Rate: Working-Age with and without Pensions, 19802003

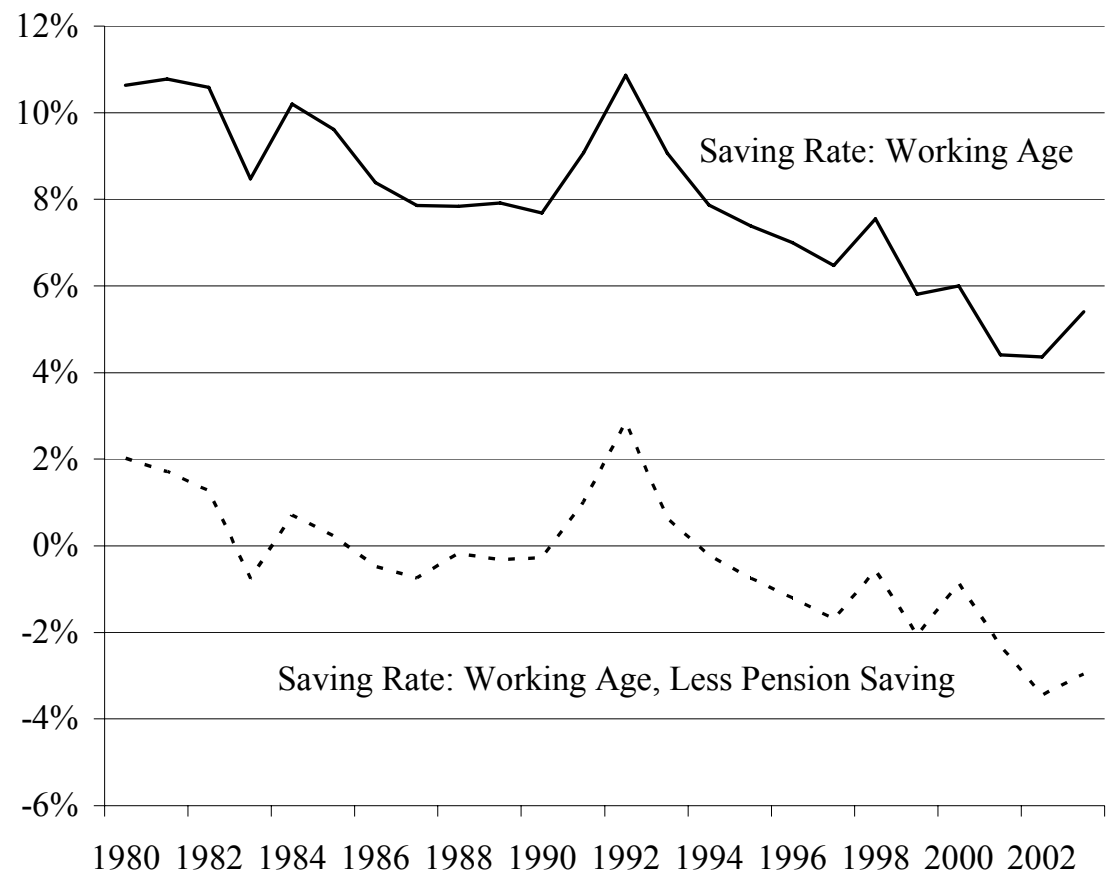

Source: Bureau of Economic Analysis. 2005. National Income and Product Accounts and authors' calculations. See Appendix 2 for details.

The key point is that adding the saving of the working-age population to pension saving results in double counting saving through employer-sponsored plans.

\section{BUSINESS SAVING AND THE SAVING RATE}

So far, the analysis has focused on "personal saving" - current income not consumed by households. As noted above, the second major component of national 
saving in the NIPA is "business saving" - current income retained by businesses. ${ }^{5}$

Together, personal and business saving comprise "private saving." Figure 6 shows the personal saving and private saving rates for the period 1980-2003. In both cases, national income - rather than personal disposable income - serves as the denominator. Because of the addition of business saving, private saving exceeds personal saving by 2 to 4 percent.

Figure 6. NIPA Saving Rate: Personal and Private Saving as a Percent of National Income, 1980-2003

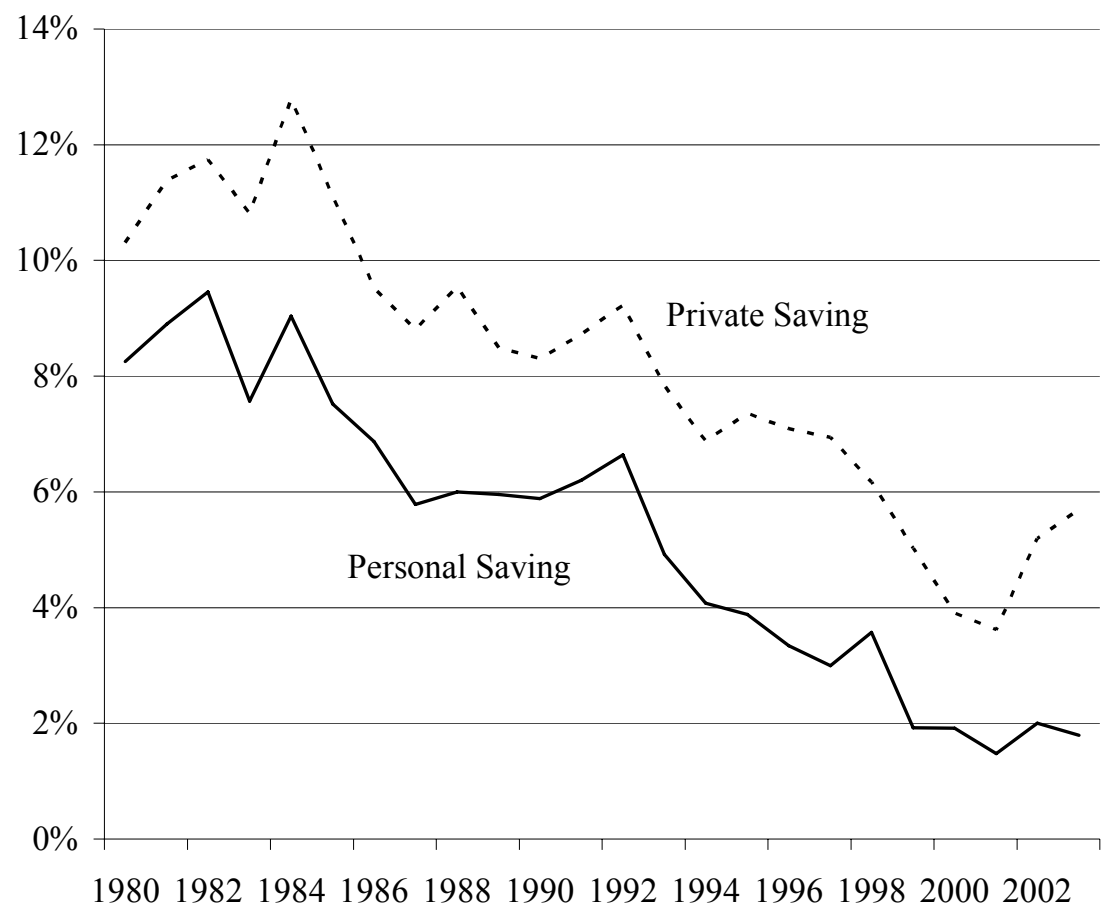

Source: Bureau of Economic Analysis. 2005. National Income and Product Accounts and authors' calculations. See Appendix 3 for details.

Focusing only on the personal saving rate understates the extent to which households are squirreling away nuts for tomorrow. First, the distinction between personal and business saving is somewhat arbitrary. For example, for NIPA purposes

\footnotetext{
${ }^{5}$ Specifically, business saving in the NIPA is the undistributed profits of corporations, which consists of after-tax profits less dividends paid out to shareholders. It also consists of an inventory valuation adjustment applied to the book value of inventories and a capital consumption adjustment applied to the book value of plant and equipment. These adjustments make the undistributed profits measure consistent with the replacement cost concept that underlies the NIPA (see gale and Sabelhaus 1999).
} 
any time a company goes from a sole proprietorship or partnership to a corporate form its saving moves from the household to the business sector. Second, saving by business whether incorporated or unincorporated adds to personal wealth since households are the ultimate owners of business assets.

The inclusion of business saving also partially addresses a major complaint raised by various analysts against the NIPA saving rate- the exclusion of capital gains from the measure. As noted above, the NIPA is designed to measure the amount of current output available for investment and thus does not include appreciation in the value of existing assets arising from price changes as part of income or saving. Yet capital gains clearly make households better able to support themselves in retirement. Business saving, which NIPA does measure, is an important component of the rising value of corporate stock. So including business saving produces a better estimate of saving for retirement by the working-age population within the NIPA framework.

Since the focus of this study is the saving of the working-age population, the next step is to allocate total business saving between those over and under age 65 . The allocation of direct equity holdings is based on holdings by age as reported in the Federal Reserve's Survey of Consumer Finances. Equities held in pensions are allocated between the young and old based on population. The definition of income also has to be broadened to the concept of "national income" to reflect the addition of business income. Figure 7 shows, for the working-age population, the "private" saving rate, which includes business as well as personal saving. This measure most accurately reflects the extent to which the working-age population is saving out of current income.

Figure 7. NIPA Saving Rate: Personal and Private Saving for Working-Age Population, 1980-2003 


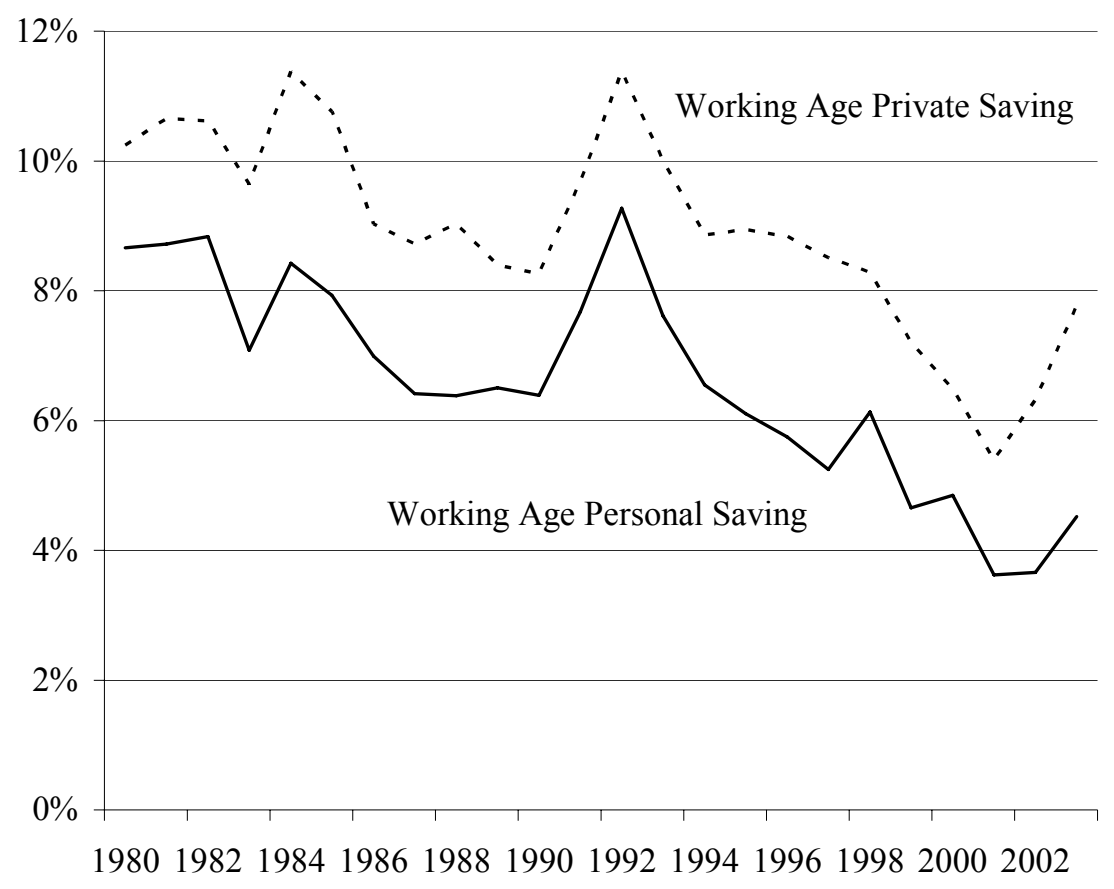

Source: Bureau of Economic Analysis. 2005. National Income and Product Accounts and authors' calculations. See Appendix 3 for details.

\section{CONCLUSION}

Three conclusions emerge from this analysis. First, adjusting the NIPA personal saving rate shows that personal saving by the working-age population is significantly higher than the reported national rate. Moreover, allocating a portion of business saving to working-age households further raises their saving rate. The pattern of saving over time is also easy to understand. It remains more or less steady until the last half of the 1990 s, at which point it declines in response to the run up in the stock market. When the bubble burst, the NIPA saving rate rebounded as people no longer had capital gains to spend.

Second, commentators should be careful not to double count saving through employer-sponsored plans by referring to pension saving and personal saving as if they are different components. In fact, for most of the time between 1980 and 2003, pension saving accounted for all of personal saving, and, today at least, saving outside of pensions is negative for the working-age population. 
Finally, the analysis (inadvertently) helps explain the puzzle surrounding the collapse of the total NIPA personal saving rate beginning in the early 1980s. While capital gains were part of the story in the 1990s, most of the downward trend can be explained by changes in the saving rate of those 65 and over. Three factors conspire to make their saving increasingly negative. Pension income - not counted in the NIPA has become an increasingly important source of the income of those 65 and over. The decline in nominal interest income as inflationary pressures waned in the 1980s reduced saving rates for the whole population, but has a particularly large effect on those 65 and over who receive a disproportionate share of the interest. And the rising cost of health care boosted expenditures - again particularly for those 65 and over who bear a disproportionate share of the burden.

In short, the total NIPA personal saving rate increasingly understates the saving of the working-age population, and the discrepancy will only increase as the share of the population 65 and over rises. However, a significant NIPA saving rate by the workingage population does not necessarily mean that they are adequately preparing for retirement since virtually all of personal saving, and most of private saving, consists of saving through pension plans. 


\section{REFERENCES}

Board of Governors of the Federal Reserve System. 1980-2004. Flow of Funds Accounts of the United States. Tables L.1 and L.213.

Board of Governors of the Federal Reserve System. 1983, 1989, 1992, 1995, 1998, 2001. Survey of Consumer Finances.

Bureau of Economic Analysis. 1950-2005. National Income and Product Accounts. Tables 2.1, 2.5.5, 5.1, 6.11 and 7.9.

Bureau of Labor Statistics. 1980-2004. Consumer Expenditure Survey. Table 3.

Bureau of Labor Statistics and Bureau of the Census. 1980-2003. Current Population Survey.

Catte, Pietro, Nathalie Girouard, Robert Price, and Christopher Andre. 2004. "Housing Markets, Wealth and the Business Cycle.” Economics Department Working Papers No. 394 (June), Paris: OECD.

Centers for Medicare and Medicaid Services. 2003. Medicare and Medicaid Statistical Supplement. Tables 12 and 94.

Chen, Yung-Ping. 1992. "The Role of Private Pensions in the Income of Older Americans," in Trends in Pensions 1992, edited by John A. Turner and Daniel J. Beller. U.S. Department of Labor. pp. 293-418.

Gale, William G. and John Sabelhaus. 1999. "Perspectives on the Household Saving Rate." Mimeo.

Haider, Steven, Michael Hurd, Elaine Reardon, and Stephanie Williamson. 2000. "Patterns of Dissaving in Retirement." Prepared for the AARP Public Policy Institute.

Lettau, Martin and Sydney C. Ludvigson. 2004. "Understanding Trend and Cycle in Asset Values: Reevaluating the Wealth Effect on Consumption." American Economic Review. 94(1): pp. 276-299.

Lusardi, Annamaria, Jonathan Skinner and Steven Venti. 2001. "Saving Puzzles and Saving Policies in the United States." Oxford Review of Economic Policy. 17(1): pp. 95-115.

Perozek, Maria G. and Marshall B.Reinsdorf. 2002. "Alternative Measures of Personal Saving." Survey of Current Business (April). 82(4): pp. 13-24.

Reinsdorf, Marshall B. 2004. “Alternative Measures of Personal Saving." Survey of Current Business (September). 84(9): pp. 17-27. 
Social Security Administration. 2004. Annual Statistical Supplement. Tables 4A.1 and 4A.2.

Social Security Administration. 1986, 1989, 1992, 1995, 1998, 2000-2004. Fast Facts and Figures About Social Security.

U.S. Census Bureau. 2004-2005. Statistical Abstract of the United States. Table 115. (2003. Table 128; 2002. Table 113; 2001. Table 120; 1999 Table 163; 1998. Table 120; 1996. Table 155; 1995. Table 151.)

U.S. Department of Labor. 2004. Private Pension Plan Bulletin: Abstract of 1999 Form 5500 Annual Reports. Table E14.

U.S. Social Security Administration. 2002. Income of the Population 55 or Older. Washington, DC: Government Printing Office. [2002 edition available at: http://www.ssa.gov/policy/docs/statcomps/income_pop55/2002/index.html] 


\section{APPENDIX 1 \\ CALCULATION OF SAVING RATE FOR THE WORKING-AGE POPULATION}

Table A1.1 summarizes the National Income and Product Accounts (NIPA) personal income, tax, outlays, and saving data for 2001. The "NIPA total" are the official numbers for the entire population. "Working-age" are our estimates of the income, tax, outlays, and saving for the working-age population (those under 65). This Appendix describes the adjustments made to each NIPA component to derive the comparable figure for the working-age population.

Table A1.1. NIPA Table. 2.1. Personal Income and Its Disposition, Major Items, 2001

\begin{tabular}{|l|l|r|r|}
\hline Line & Item & \multicolumn{1}{|c|}{$\begin{array}{c}\text { NIPA total } \\
\text { billions }\end{array}$} & Working-age \\
\hline 1 & Personal Income & $\$ 8,724.1$ & $\$ 7,421.5$ \\
\hline 25 & Less: Personal current taxes & $1,237.3$ & $1,143.5$ \\
\hline 26 & Equals: Disposable personal income & $7,486.8$ & $6,278.1$ \\
\hline 27 & Less: Personal outlays & $7,354.5$ & $6,001.2$ \\
\hline 33 & Equals: Personal saving & 132.3 & 276.9 \\
\hline 34 & Personal saving as a percentage of & & 4.8 \\
\hline & disposable personal income & 1.8 & 4.4 \\
\hline
\end{tabular}

\section{Allocation of Personal Income to Working-Age Population}

The first step in the process is to allocate the components of personal income shown in Table A1.2 to the working-age population. In general, ratios of income for the workingage (under 65) population to that of the total population are derived from the 2001 Survey of Consumer Expenditures (CEX). When the NIPA and CEX definitions are not consistent, alternative approaches are described in detail below.

Table A1.2. Personal Income from NIPA Table. 2.1, 2001

\begin{tabular}{|l|l|r|r|r|}
\hline Line & Item & NIPA total & \multicolumn{2}{|c|}{ Working-age } \\
\cline { 4 - 5 } & & billions & Percent of total & \multicolumn{1}{|c|}{ Billions } \\
\hline 1 & Personal income & $\$ 8,724.1$ & & $\$ 7,421.5$ \\
\hline 2 & Compensation of employees, received & $5,942.1$ & $96.4 \%$ & $5,727.4$ \\
\hline 9 & Proprietors' income with IVA and CCA & 771.9 & 91.5 & 706.3 \\
\hline 12 & Rental income of persons with CCA & 167.4 & 72.0 & 120.6 \\
\hline 13 & Personal income receipts on assets & & & \\
\hline 14 & Personal interest income & 1011.0 & 69.8 & 705.9 \\
\hline 15 & Personal dividend income & 369.0 & 70.3 & 259.6 \\
\hline 16 & Personal current transfer receipts & & & \\
\hline 17 & Government social benefits to persons & & & \\
\hline 18 & OASDHI benefits & 668.5 & 23.6 & 157.9 \\
\hline 19 & Government UI benefits & 31.7 & 91.9 & 29.1 \\
\hline 20 & Veterans benefits & 26.7 & 91.9 & 24.5 \\
\hline 21 & Family assistance & 18.1 & 81.9 & 14.8 \\
\hline 22 & Other & 398.9 & 84.3 & 336.1 \\
\hline 23 & Other current transfer receipts, from & 50.0 & 87.9 & 44.0 \\
\hline 24 & business (net) & & & \\
\hline
\end{tabular}


Table 3 of the CEX is used to allocate the following components of personal income to the working-age population. "Compensation of employees, received" (line 2) is allocated based on "wages and salaries." "Proprietors' income with IVA and CCA" (line 9) is allocated based on "self-employment income." "Government unemployment insurance benefits" (line 19) and "veterans benefits" (line 20) are allocated based on "unemployment and workers' compensation, veterans' benefits." "Family assistance" (line 21) is allocated based on "public assistance, supplemental security income, food stamps." "Other current transfer receipts, from business (net)" (line 23) is allocated based on "other income." "Contributions for government social insurance" (line 24) is allocated based on "wages and salaries."

"Other" (line 22) requires combining other data sources with the CEX. Medicaid accounts for about 50 percent of this category. The Medicaid amount is allocated to the working-age population based on "Medicaid payments, by eligibility group," Table 94 in the Centers for Medicare and Medicaid Services publication, Health Care Financing Review Medicare and Medicaid Statistical Supplement, 2003. The other 50 percent is allocated based on CEX "regular contributions for support."

For a number of components of NIPA personal income, the CEX does not include comparable information. Fortunately, in most instances the 2001 Survey of Consumer Finances (SCF) provides helpful data. In the case of "rental income of persons" (line 12), the SCF provides data on "primary housing" ownership and rental income by age group. This information is applied to the detail on "rental income of persons by legal form of organization and type of income" provided in NIPA Table 7.9.

In the case of "personal interest income" (line 14) and "personal dividend income line (line 15), it is necessary to augment the SCF data with data from the Federal Reserve's Flow of Funds. For both components, the first step is to use the Flow of Funds (Table L. 1 in the case of interest and Table L.213 in the case of dividends) to determine the holders of the relevant assets. Holdings by governments and foreign entities are subtracted from the total. With regard to debt, mortgages are also subtracted to conform to the NIPA treatment of housing debt. The remaining holders are combined into groups such as households, banking and saving, insurance, pension, etc. Data from the SCF are then used to allocate these holdings by age. Interest and dividend income is then allocated to the working-age population based on asset holdings by age. The one exception is the allocation of dividends and interest arising from pension assets. Here, the allocation to the working-age is based on population. The rationale is that pension assets back the benefits of current retirees as well as reflect funding for today's workers.

Finally, OASDHI benefits are allocated to the OASDI and HI programs based on agency data. The percent of OASI and DI benefit payments going to working-age individuals is taken from Fast Facts and Figures, OASDI Program: Beneficiaries, by Age, various years. The percent of HI benefit payments going to working-age individuals is based on the ratio of disability to total payments, taken from Table 12, Medicare Program Payments, 
by Type of Coverage and Type of Entitlement: Calendar Years 1967-2001 in the CMS Medicare and Medicaid Statistical Supplement, 2003.

\section{Allocation of Taxes to the Working-Age Population}

"Personal current taxes" (line 25) in NIPA are allocated to the working-age population based on "personal taxes" reported in Table 3 of the CEX.

Table A1.3. Personal Disposable Income from NIPA Table. 2.1, 2001

\begin{tabular}{|l|l|r|r|r|}
\hline Line & Item & NIPA total & \multicolumn{2}{|c|}{ Working-age } \\
\cline { 4 - 5 } & & billions & Percent of total & \multicolumn{1}{c|}{ Billions } \\
\hline 1 & Personal income & $\$ 8,724.1$ & & $\$ 7,421.5$ \\
\hline 25 & Less: Personal current taxes & $1,237.3$ & $92.4 \%$ & $1,143.5$ \\
\hline 26 & Equals: Disposable personal income & $7,486.8$ & & $6,278.1$ \\
\hline
\end{tabular}

\section{Allocation of Outlays to the Working-Age Population}

Savings of the working-age population is equal to its personal income less taxes less personal outlays. Personal outlays in the NIPA consist primarily of personal consumption expenditures plus smaller amounts of personal interest payments and personal current transfers (Table A1.3).

Table A1.4. Personal Outlays from NIPA Table. 2.1, 2001

\begin{tabular}{|l|l|r|r|r|}
\hline Line & Item & \multirow{2}{*}{$\begin{array}{c}\text { NIPA total } \\
\text { billions }\end{array}$} & \multicolumn{2}{|c|}{ Working-age } \\
\cline { 4 - 5 } & & & Percent of total & \multicolumn{1}{c|}{ Billions } \\
\hline 27 & Personal outlays & $7,354.5$ & & $\$ 6,001.2$ \\
\hline 28 & Personal consumption expenditures & $7,055.0$ & $81.3 \%$ & $5,732.7$ \\
\hline 29 & Personal interest payments & 212.2 & 90.4 & 191.8 \\
\hline 30 & Personal current transfer payments & 87.2 & 88.0 & 76.8 \\
\hline
\end{tabular}

Addressing the smaller categories first, "Personal interest payments" (line 29) are allocated to the working-age population based on holdings by age of non-mortgage debt as reported in the SCF. "Personal current transfer payments" (line 30) are allocated based on the ratio of the under-age- 65 population to the total as reported in the March Supplement to Census Bureau's Current Population Survey for 2001.

"Personal consumption expenditures" (line28) are allocated to the working-age population using the detail provided in NIPA Table 2.5.5 (see Table A1.4 below for selected major items). In virtually all cases the allocation is based on Table 3 of the Consumer Expenditure Survey (CEX). "Food and tobacco" (line 2 in NIPA Table 2.5.5) is allocated based on "food; tobacco; and alcoholic beverages." "Clothing, accessories, and jewelry" (line 11) is allocated based on "apparel and services." "Personal care" (line 20 ) and is allocated based on "personal care, products, and services." "Housing" (line 23 ) is allocated based on "housing (shelter)." "Household operations" (line 28) is allocated based on "housing (non-shelter)." "Personal business" (line 60) is allocated based on "cash contributions." "Transportation" (line 68) is allocated based on 
"transportation." "Recreation" (line 86) is allocated based on "entertainment; and reading." "Education and research" (line 104) is allocated based on "education." "Religious and welfare activities" (line 108) is allocated based on "miscellaneous."

"Foreign travel and other" (line 109 in NIPA Table 2.5.5) is allocated based on the ratio of the under-age- 65 population to the total as reported in the March Supplement to Census Bureau's Current Population Survey for 2001.

Table A1.5. Personal Consumption Expenditure from NIPA Table. 2.5.5, 2001

\begin{tabular}{|l|l|r|r|r|}
\hline Line & Item & \multirow{2}{*}{$\begin{array}{c}\text { NIPA total } \\
\text { billions }\end{array}$} & \multicolumn{2}{|c|}{ Working-age } \\
\cline { 4 - 5 } & & & Percent of total & \multicolumn{1}{|c|}{ Billions } \\
\hline 1 & Personal consumption expenditures & $1,052.0$ & & $\$ 5,750.5$ \\
\hline 2 & Food and tobacco & 397.1 & $86.4 \%$ & 908.7 \\
\hline 11 & Clothing, accessories, and jewelry & 94.5 & 89.8 & 356.7 \\
\hline 20 & Personal care & $1,073.7$ & 83.8 & 79.2 \\
\hline 23 & Housing & 740.3 & 83.3 & 937.7 \\
\hline 28 & Household operations & $1,327.3$ & 63.2 & 617.6 \\
\hline 44 & Medical care & 536.5 & 75.0 & 838.4 \\
\hline 60 & Personal business & 872.4 & 88.4 & 402.3 \\
\hline 68 & Transportation & 604.0 & 88.5 & 770.8 \\
\hline 86 & Recreation & 178.1 & 94.7 & 534.5 \\
\hline 104 & Education and research & 186.5 & 76.4 & 168.6 \\
\hline 108 & Religious and welfare activities & -7.4 & 88.0 & 142.4 \\
\hline 109 & Foreign travel and other & & & -6.5 \\
\hline
\end{tabular}

"Medical care" (line 44 in NIPA Table 2.5.5) requires a more complicated calculation because the CEX does not include medical costs paid by health insurance providers, while NIPA does. The allocation of NIPA medical expenditures is based on the table "National Health Expenditures by Type," published in the Statistical Abstract of the United States (see Table A1.6).

Table A1.6. National Health Expenditures by Type, Table No. 115, 2001

\begin{tabular}{|l|r|r|r|}
\hline \multirow{2}{*}{ Item } & \multicolumn{1}{|c|}{ Total } & \multicolumn{2}{|c|}{ Working-age } \\
\cline { 3 - 4 } & billions & Percent of total & \multicolumn{1}{c|}{ Billions } \\
\hline Total & $\$ 1,420.7$ & $63.2 \%$ & $\$ 897.3$ \\
\hline Private expenditures & 768.4 & & 522.9 \\
\hline Health services and supplies & 751.0 & & 507.6 \\
\hline Out-of-pocket payments & 200.5 & 69.5 & 139.4 \\
\hline Insurance premiums & 495.6 & 66.7 & 330.8 \\
\hline Other & 54.9 & 68.2 & 37.4 \\
\hline Medical research & 2.7 & 88.0 & 2.4 \\
\hline Medical facilities construction & 14.7 & 88.0 & 12.9 \\
\hline Public expenditures & 652.3 & & 374.4 \\
\hline Health services and supplies & 619.0 & & 345.1 \\
\hline Medicare & 246.5 & 15.0 & 37.0 \\
\hline Public assistance medical payments & 232.2 & 74.1 & 172.1 \\
\hline Temporary disability insurance & 0.0 & 88.0 & 0.0 \\
\hline Workers' compensation (medical) & 27.6 & 100.0 & 27.6 \\
\hline Defense Dept. hospital, medical & 15.2 & 100.0 & 15.2 \\
\hline
\end{tabular}




\begin{tabular}{|l|r|r|r|}
\hline Maternal, child health programs & 2.8 & 100.0 & 2.8 \\
\hline Public health activities & 48.3 & 100.0 & 48.3 \\
\hline Veterans' hospital, medical care & 21.7 & 88.0 & 19.1 \\
\hline Medical vocational rehabilitation & 0.8 & 100.0 & 0.8 \\
\hline State and local hospitals & 14.0 & 88.0 & 12.3 \\
\hline Other & 9.8 & 100.0 & 9.8 \\
\hline Medical research & 28.8 & 88.0 & 25.4 \\
\hline Medical facilities construction & 4.5 & 88.0 & 4.0 \\
\hline
\end{tabular}

Source: U.S. Census Bureau, Statistical Abstract of the United States: 2004-2005. Table No. 115.

The allocation of the "health services and supplies" component of "private expenditures" is based on CEX Table 3. Out-of pocket payments and insurance premiums are allocated based on "health care (not insurance) and "health insurance." "Other" is based on "health care." The allocations for "Medicare" and "public assistance medical payments" are based on agency expenditure data. The remaining items are distributed by either population or allocated entirely to the working-age population.

Deducting total outlays of $\$ 6,001.2$ billion for the working-age population from disposable personal income for the working-age population of $\$ 6,278.1$ billion yields personal saving of $\$ 276.9$ billion for the working-age or 4.4 percent of this group's disposable personal income.

\section{APPENDIX 2 \\ CALCULATION OF NON-PENSION SAVING}

To calculate non-pension saving for the working-age population involves subtracting from their total savings, of $\$ 276.9$ billion, amounts contributed to pension plans by employers and employees, and the earnings on the accumulated assets in these plans. This is done in two steps. The first is to calculate total pension contributions and earnings on pension assets and second to allocate a portion of these pension contributions and earnings to the working-age population.

NIPA Table 6.11 provides data on employer contributions to private defined benefit and defined contribution plans and employer and employee contributions to public plans. The missing component is employee contributions to private plans. This is estimated by subtracting NIPA reported employer contributions to private plans from total contributions to private plans as reported in the Department of Labor's Form 5500. Some projection is required for 2001 since the most recent 5500 Report is for 1999.

Once total pension contributions are estimated, the share going to the working-age population is calculated using the proportion of wages and salaries in Table 3 of the CEX earned by those under age 65 . 
The other component of pension saving is the interest and dividends earned on accumulated assets. The Flow of Funds identifies the amount of credit instruments and equities held in pension reserves. This proportion of total assets is applied to the NIPA interest and dividend totals to estimate earnings on pension reserves.

The share of returns on accumulated pension assets attributable to the working-age population is determined on the basis of population, as is done in the calculation of total saving by the working-age population.

Non-pension saving for the working-age population is then equal to their total saving minus their pension saving. Finally, the non-pension saving rate is non-pension saving divided by disposable personal income for the working-age population.

\section{APPENDIX 3 \\ ALLOCATION OF BUSINESS SAVING TO WORKING-AGE POPULATION}

Business saving, which consists of "Undistributed corporate profits with inventory valuation and capital consumption adjustments," is found on line 5 in NIPA Table 5.1: Saving and Investments. Business saving is allocated to the working-age population based on their receipt of dividends as summarized in Appendix 1.

National income is allocated for the working-age population in the same proportion as personal income shown in Appendix 1.

APPENDIX 4

EXTENDING ESTIMATES FOR PERIOD 1980-2003

Estimating the saving rate for the working-age population for the period 1980 through 2003 generally involves nothing more than beginning with the given year's NIPA figures and applying the corresponding working-age ratios.

This process is somewhat complicated by the limited availability of CEX and SCF data. CEX Table 3 data are available only as far back as 1984. For the years 1980 through 1983, the 1984 CEX ratio is applied to the corresponding year's NIPA figures. SCF data are available at three year intervals between 1983 and 2001, excluding 1986. The working-age ratios for the years 1983 and 2001 are applied to the NIPA figures for the periods 1980 through 1982 and 2002 through 2003 respectively. For years between 1983 and 2001 for which SCF data are not available, the calculation is based on a linear 
interpolation of the working-age ratios from the closest surrounding years. Because the year-to-year change in these ratios was typically small, these simplifications prove adequate in providing a close approximation.

In certain cases, additional imputations are necessary as dictated by the availability of other data sources. For example, pension plan contributions, as reported in form 5500 filings (used in the calculation of employee contributions to pension plans) are unavailable for years beyond 1999. A detailed breakdown of national health expenditures, as reported in the Statistical Abstract of the United States (used in the calculation of working-age medical care expenditures) is only available for limited years between 1980 and 1988. In these cases, data are extrapolated beyond the closest available year, interpolated between available years, or substituted for the closest available year, at the authors' discretion. 


\section{RECENT WORKING PAPERS FROM THE}

\section{CEnTER FOR RETIREMENT RESEARCH AT Boston COLleGE}

Top Ten Myths of Social Security Reform

Jeffrey R. Brown, Kevin Hassett and Kent Smetters, October 2005

What Replacement Rates Do Households Actually Experience in Retirement?

Alicia H. Munnell and Mauricio Soto, August 2005

Bequests, Inheritances and Family Traditions

Donald Cox and Oded Stark, August 2005

Local Labor Market Conditions and Retirement Behavior

Dan A. Black and Xiaoli Liang, May 2005

Validation Study of Earnings Data in the SIPP—Do Older Workers Have Larger Measurement Error?

Peter Gottschalk and Minh Huynh, May 2005

Investment Choice in the Swedish Premium Pension Plan

Mårten Palme, Annika Sundén, and Paul Söderlind, April 2005

Design and Implementation Issues in Swedish Individual Pension Accounts R. Kent Weaver, March 2005

Lashed to the Mast?: The Politics of Notional Defined Contribution Pension Reforms

Sarah M. Brooks and R. Kent Weaver, January 2005

Understanding Expenditure Patterns in Retirement

Barbara A. Butrica, Joshua H. Goldwyn, and Richard W. Johnson, January 2005

Changes in the Distribution of Long-Run Earnings and Retirement Incomes-Have Recent Cohorts Fallen Behind?

Peter Gottschalk and Minh Huynh, January 2005

All working papers are available on the Center for Retirement Research website (http://www.bc.edu/crr) and can be requested by e-mail (crr@bc.edu) or phone (617-552-1762). 